\title{
Implementasi PPDM Tahun Pertama bagi Masyarakat Pesisir Danau Limboto melalui Penguatan Sumber Daya Manusia dan Iptek Manajemen Pemanfaatan Eceng Gondok sebagai Produk Unggulan
}

\author{
Tineke Wolok ${ }^{1}$, Ismet Sulila ${ }^{2}$, Weny Almoravid Dungga ${ }^{3}$ \\ 1, 2, 3 Universitas Negeri Gorontalo
}

\begin{tabular}{ll}
\hline Article History & ABSTRACT \\
\hline Received 07.02.2019 & THE IMPLEMENTATION OF PPDM FIRST YEAR FOR PEOPLE OF COAST \\
Received in revised form & OF LAKE LIMBOTO THROUGH ENFORCEMENT OF HUMAN RESOURCE \\
Accepted 01.04.2019 & AND SCIENCE AND TECHNOLOGY (IPTEK) OF MANAGEMENT OF \\
Available online 30.04.2019 & WATER HYACINTH USE AS EXCELLENT PRODUCT. Iluta Village is \\
& situated in coastal of Limboto Lake and frequently encounters flood problem \\
& in the rainy season and also serious problem namely siltation of Limboto Lake \\
& as caused by the massive growth of water hyacinth. There were three main \\
& problems handled by this program at the first year, namely: 1) effort of \\
& reducing siltation of Limboto Lake sustainably through removal and use of \\
& the water hyacinth as craft material, 2) empowerment of community economic \\
& through capacity building of business management of varied water hyacinth \\
& woven crafts, and 3) capacity building of human resource of local community \\
& as target group. The applied method encompassed: 1) determining problems \\
priority to be solved and divided them into three-year activity, 2) doing & reconstruction and improvement based on the problems gradually for every \\
& year, 3) improvement was performed based on local community character \\
& approach. The findings showed: 1) use of water hyacinth as handicrafts \\
product could help reducing Lake Siltation, 2) management ability in business & management started to grow, and 3) improvement of human resource ability \\
for the coastal community as the target group.
\end{tabular}

Keywords: Empowerment, Human Resource, Management.

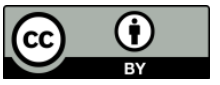

This is an open access article distributed under the terms of the Creative Commons Attribution 4.0 International License, which permits unrestricted use, distribution, and reproduction in any medium, provided the original work is properly cited. ๑) 2019 Tineke Wolok, Ismet Sulila, Weny Almoravid Dungga.

\section{PENDAHULUAN}

Undang-undang RI Nomor 6 tahun 2014 tentang desa telah membawa dampak pada otonomi desa dalam pembangunan masyarakat. Kondisi tersebut dipandang sebagai

${ }^{2}$ Corresponding author: Fakultas Ekonomi Universitas Negeri Gorontalo. Jl. Jenderal Sudirman No.6, Dulalowo Tim., Kota Tengah, Kota Gorontalo 96128; Email: ismet.sulila@gmail.com 
peluang dan tantangan dalam pemanfaatan potensi wilayah. Desa Iluta merupakan salah satu desa di kabupaten Gorontalo yang menjadi desa binaan Universitas Negeri Gorontalo. Beberapa kegiatan akademik juga dilaksanakan disini. Kondisi tingkat ekonomi masyarakat desa berada pada menengah ke bawah yang sebagian besar mata pencahariannya bergantung di Danau Limboto Kabupaten Gorontalo. Secara geografis Desa Iluta berbatasan langsung dengan danau Limboto dan wilayah Kota Gorontalo.

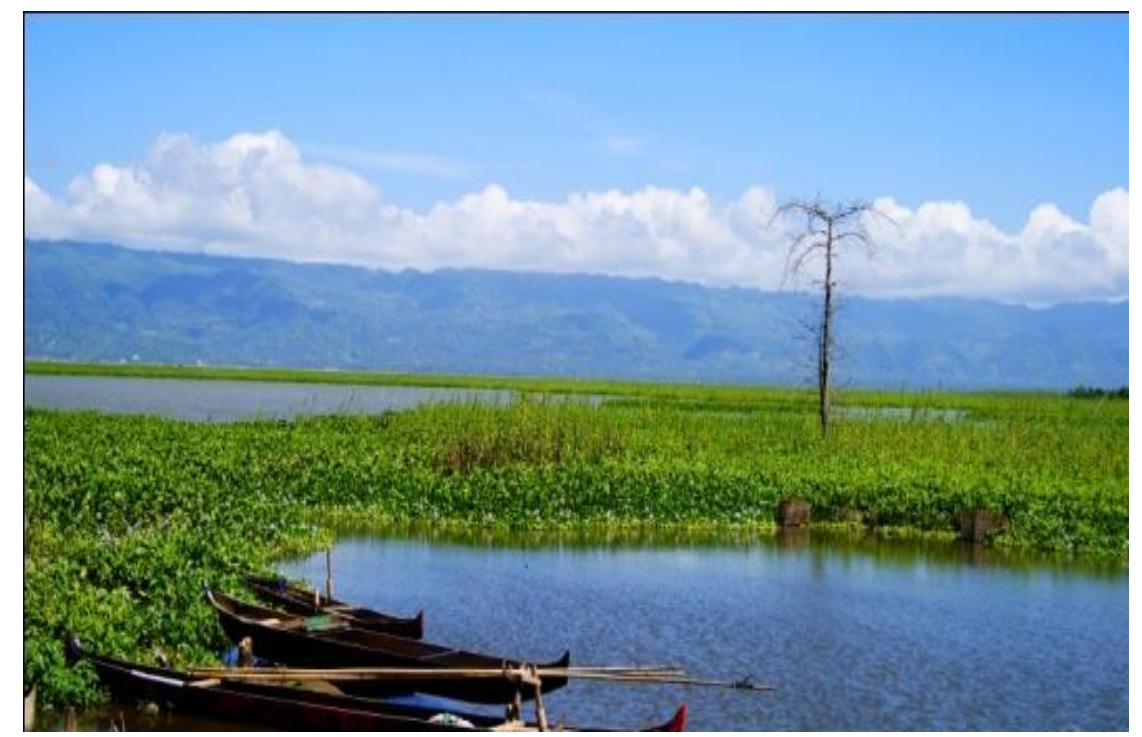

Gambar 1. Eceng gondok di pesisir Danau Limboto

Desa Iluta memiliki luas wilayah kurang lebih 120 Ha terdiri atas 5 buah dusun. Masyarakat desa lebih banyak berprofesi sebagai nelayan dengan cara budidaya beberapa jenis ikan danau melalui jarring (keramba). Danau Limboto merupakan satu-satunya sumber penghasil ikan danau terbesar di Gorontalo. Dominasi masyarakat pesisir sebagai nelayan yang menggantungkan danau limboto sebagai sumber mata pencaharaian utama telah menempatkan danau Limboto sebagai sumber alam penting bagi masyarakat. Namun demikian hasil kajian menunjukkan bahwa mulai terdapat kehawatiran masyarakat tentang existensi danau limboto yang disebabkan oleh beberapa kondisi, yaitu: 1) adanya pendangkalan danau Limboto, 2) masifnya pertumbuhan eceng gondok, 3) tingginya debit air pada saat musim penghujan.

Namun di sisi lain penghasilan yang diperoleh dari profesi sebagai nelayan belumlah cukup untuk memenuhi kebutuhan hidup anggota keluarga. Disamping itu pula dalam melaksanakan usaha jaring ikan masalah yang dihadapi masyarakat nelayan adalah banyaknya tumbuhan eceng gondok di wilayah danau Limboto yang dirasakan cukup mengganggu perkembangan budidaya ikan yang dilaksanakan masyarakat.Oleh karena itu dibutuhkan pula upaya lain dalam mencapai kesejahteraan. Eceng gondok yang memiliki nama ilmiah Eichornia crassipes merupakan tumbuhan air dan lebih sering dianggap sebagai tumbuhan pengganggu perairan. Eceng gondok memiliki tingkat pertumbuhan yang sangat cepat. Dalam tempo 3 s.d 4 bulan saja tumbuhan ini mampu menutupi lebih dari $70 \%$ permukaan danau. Cepatnya pertumbuhan eceng gondok dan tingginya daya tahan hidup menjadikan tumbuhan ini sangat sulit diberantas. Eceng gondok berpotensi menghilangkan air permukaan sampai 4 kali lipat jika dibandingkan dengan permukaan terbuka. Pertumbuhan populasi eceng gondok yang tidak terkendali menyebabkan pendangkalan ekosistem perairan dan tertutupnya sungai serta danau, dimana hal ini sebagaimana terlihat nyata di danau Limboto Kabupaten Gorontalo. 
Kondisi di atas menjadi isu penting untuk dirumuskan solusi konkrit yang melibatkan partisipasi aktif masyarakat setempat. Begitu pentingnya pelestarian danau Limboto bagi masyarakat setempat, maka sejak tahun 2016 Pemerintah Kabupaten Gorontalo telah mencanangkan festival danau Limboto yang dilaksanakan setiap bulan September di lokasi wisata pendaratan Presiden Soekarno di Desa Iluta. Pengembangan wisata merupakan bagian yang tidak terpisahkan dengan upaya-upaya konservasi, pemberdayaan ekonomi lokal dan mendorong respek yang lebih tinggi terhadap perbedaan kultur atau budaya (Fandeli, 2000; Damanik \& Weber, 2006; Satria, 2009). Berbagai aktifitas produktif melibatkan masyarakat Gorontalo dilaksanakan pada festival dan lomba kriya eceng gondok ini.

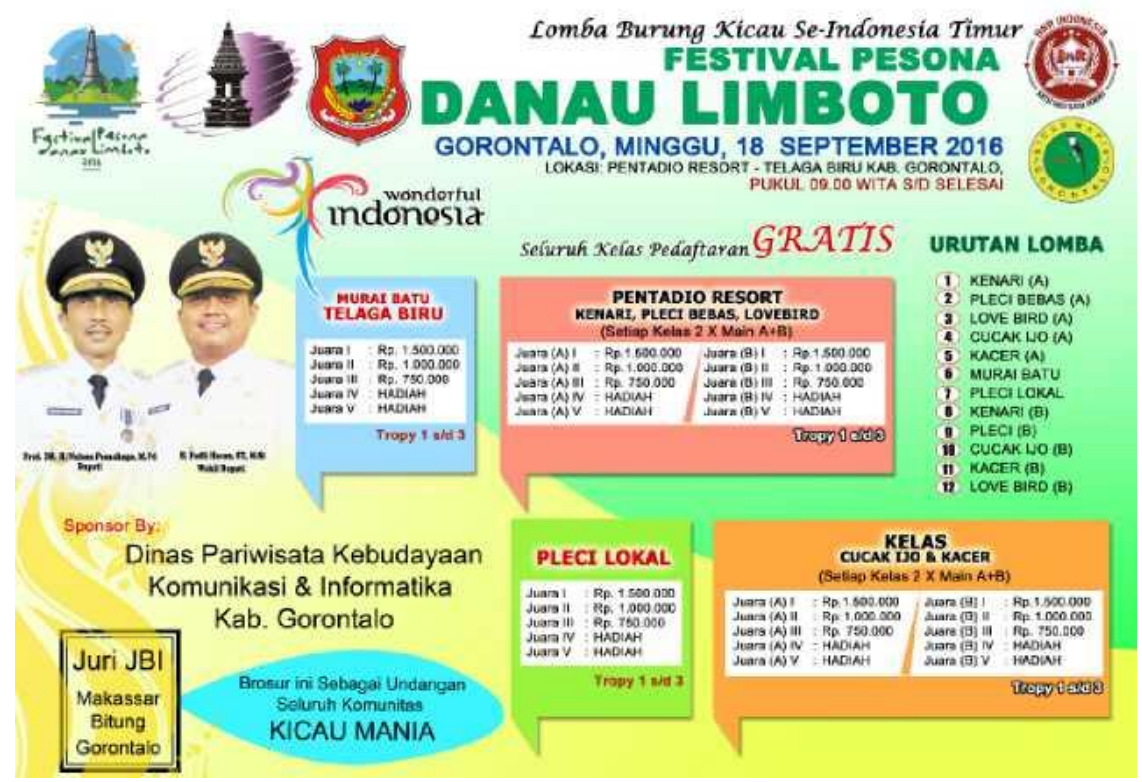

Gambar 2. Promosi Festival Danau Limboto

Sebagai desa pesisir terdapat tiga masalah pokok yang dihadapi masyarakat desa ini yaitu bagaimana: 1) Penanggulangan masalah lingkungan yaitu pendangkalan danau Limboto oleh eceng gondok dilokasi Desa Iluta yang tumbuh sangat masif, 2) Pemberdayaan ekonomi masyarakat melalui pemanfaatan potensi eceng gondok sebagai produk kerajinan yang bernilai ekonomi tinggi, 3) Mengoptimalkan kawasan danau Limboto beserta fasilitas pendukung wisata disekitarnya untuk meningkatkan kesejahteraan masyarakat Desa Iluta.

Di beberapa negara, pemberantasan eceng gondok secara mekanik, kimia dan biologi tidak pernah memberikan hasil yang optimal. Oleh karena itu sangat dibutuhkan metode lain dalam penanganannya. Metode dimaksud adalah partisipasi aktif kelompok masyarakat yang berkelanjutan dalam pengangkatan dan pemanfaatan eceng gondok sebagai ragam produk kerajinan tangan unggulan khas Desa Iluta. Ragam produk eceng gondok meliputi: 1) tas, 2) kursi, 3) partisi ruangan, 4) lampu hias, 5) keranjang, 6) sandal, 7) tempat tisu, 8) pas bunga, 9) produk lainnya. Dampak nyata PPDM dan RPJM desa akan bersinergi dan saling mengisi satu sama lain yang dapat dilihat keterkaitannya pada Gambar 3. 


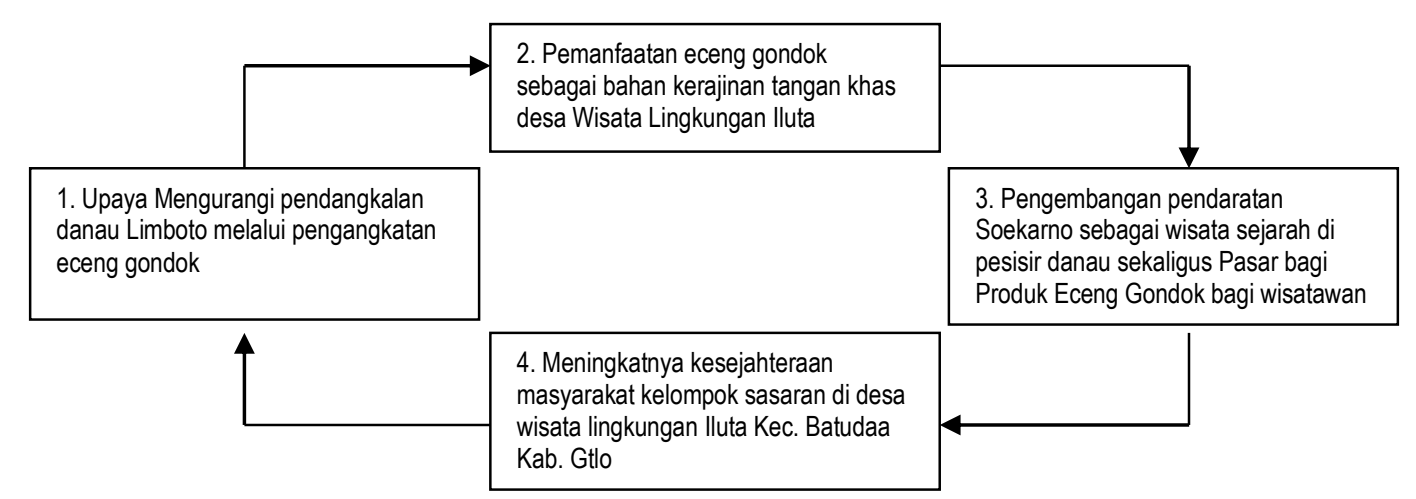

Gambar 3. Keterkaitan dampak nyata PPDM Desa Iluta Kec. Batudaa Kab. Gorontalo

\section{METODE PELAKSANAAN}

Metode pelaksanaan didasarkan pada analisis data di lapangan. Analisis data sebagai suatu proses yang merinci usaha formal untuk menemukan tema dan merumuskan ide sebagai yang disarankan oleh data, dan sebagai usaha untuk memberikan bantuan pada tema dan ide tersebut (Aries, 2010). Oleh karena itu metode pelaksanaan kegiatan ini meliputi: 1) menetapkan prioritas masalah yang akan dibenahi pada tahun kegiatan, 2) melakukan rekonstruksi dan pembenahan berdasarkan masalah secara bertahap, 3) pembenahan dilakukan berdasarkan pendekatan karakter lokal masyarakat setempat, 4) menyiapkan metode dan penerapan teknologi sesuai dengan prioritas masalah dan target yang ditetapkan.

Secara rinci metode pendekatan penerapan Iptek dapat dijelaskan sebagai berikut: 1) Pemanfaatan Eceng Gondok. Ragam produk eceng gondok sebagai industri kerajinan banyak digeluti masyarakat. Industri adalah kegiatan ekonomi yang mengolah bahan mentah, bahan baku, barang setengah jadi atau barang jadi menjadi barang dengan nilai yang lebih tinggi lagi penggunaannya, termasuk kegiatan rancang bangun industri dan perekayasaan industri (Kartasapoetra, 2000). Dalam mengembangkan ragam produk eceng gondok maka pendekatan yang dilakukan adalah sosial kemasyarakatan dalam bentuk kampanye terbuka pada kelompok masyarakat sasaran di pesisir danau limboto desa wisata Iluta. Bersama pemerintah dan masyarakat menetapkan target terukur wilayah/lokasi pembersihan yang dilaksanakan dua kali dalam setahun. 2) Manajemen. Aspek manajemen sangat penting dalam tata kelola usaha. Lemahnya kemampuan manajemen ini mengakibatkan pengusaha kecil tidak mampu mengelola usahanya dengan baik (Kuncoro, 2006). Oleh karena itu skala prioritas melalaui manajemen strategis harus diperhatikan. Manajemen strategis merupakan suatu rencana yang disusun dan dikelola dengan memperhitungkan berbagai sisi dengan tujuan agar pengaruh rencana memberikan dampak positif bagi organisasi dalam jangka panjang (Fahmi, 2015).

Pendekatan manajemen modern bagi kelompok usaha masyarakat dengan cara menetapkan secara profesional tentang pembenahan yang harus dilakukan dalam menjalankan usaha. Pendekatan ini juga mengacu pada upaya pemerintah dalam pembinaan UMKM yang dituangkan dalam kebijakan pemerintah. Manajemen profesional diantaranya dilakukan dengan cara memberikan pengetahuan pada kelompok usaha yang dimulai dari perencanaan sampai evaluasi usaha hingga keberlanjutan usaha pada masa yang akan datang. Upaya lainnya adalah 
pengorganisasian kelompok usaha sehingga jelas dirinci pembagian tugas masing-masing anggota kelompok. Disamping itu pula manajemen perlu menekankan pada pengembangan kerajinan eceng gondok menjadi produk unggulan dengan ciri khas dan motif tertentu, seperti motif ikan, pohon kelapa, motif masjid, dan sebagainya. 3) Sumber daya manusia (SDM). Pengembangan usaha kelompok yang berkelanjutan membutuhkan bimbingan teknis aspek keuangan, produksi, pemasaran dan aspek penting lainnya (Dungga: 2018). Dengan adanya bimbingan teknis sumber daya manusia dapat berdampak pada kemampuan kelompok sasaran. Meningkatnya kemampuan kelompok sasaran dalam fokus penerapan metode penyiapan bahan baku untuk menjamin kontinuitas produksi (Sulila: 2018). Dibutuhkan fokus pelatihan SDM sesuai urutan kegiatan produksi. Hal ini dilakukan untuk meningkatkan kualitas SDM. Misalnya tenaga spesialis pengembangan desain anyaman, spesialis ornamen, spesialis motif dan desain produk. Selain itu SDM akan juga diarahkan pada keahlian anggota dalam mewujudkan keunggulan anyaman eceng gondok dengan ciri khas desa wisata lingkungan Iluta sebagai unggulan yang hanya dapat diperoleh di desa ini. Untuk dapat melakukan hal tersebut maka tim pengabdi bekerja sama dengan instansi terkait dalam hal ini Dewan Kerajinan Nasional Daerah dan Dinas Koperindag Kabupaten Gorontalo dan Balitbang Gorontalo.

\section{HASIL DAN PEMBAHASAN}

Sinergi Pemeritah dan Perguruan Tinggi serta masyarakat sangat diperlukan dalam upaya pemberdayaan untuk meningkatkan kesejahteraan (Sulila: 2016). Menurut Mubarak (2010) pemberdayaan masyarakat dapat diartikan sebagai upaya untuk memulihkan atau meningkatkan kemampuan suatu komunitas untuk mampu berbuat sesuai dengan harkat dan martabat mereka dalam melaksanakan hak-hak dan tanggungjawab selaku anggota masyarakat. Dalam pemberdayaan masyarakat Desa Iluta dilaksanakan skala prioritas masalah untuk melahirkan solusi melalui penerapan Iptek. Secara rinci solusi atas permasalahan yang dihadapi pada kegiatan ini meliputi: 1) Pembesihan eceng gondok. Mobilisasi masyarakat pesisir danau Limboto khususnya Desa Iluta untuk melakuan upaya konkrit pengangkatan eceng gondok, untuk selanjutnya diproses digunakan sebagai bahan baku kerajinan tangan. Kegiatan ini akan dilaksanakan tahun pertama, kedua dan ketiga PPDM. 2) Pelaksanaan bimbingan teknis kegiatan pembuatan ragam produk eceng gondok beserta tatakelola/manajemen yang dimulai dari masalah sumberdaya manusia, bahan baku, produksi, produk dan pemasaran. Kegiatan ini dilaksanakan selama tiga tahun, dengan memprioritaskan penyelesaian masalah berdasarkan target tahunan. 3) Pengembangan rumah pendaratan Soekarno yang terletak di Desa Iluta pesirir danau limboto sebagai wisata lingkungan dan sejarah yang sekaligus pengunjung dapat membeli ragam produk kerajinan eceng gondok yang ditawarkan oleh kelompok usaha masyarakat.

Berdasarkan kesepakatan dengan mitra maka pendekatan kerja yang digunakan PPDM dapat diurai melalui prosedur kerja sebagai berikut:

1) Pengangkatan Eceng Gondok di pesisir danau limboto dan wisata pendaratan Soekarno; Prosedur kerja meliputi: 1) koordinasi internal, 2) identifikasi/survei lapangan, 2) sosialisasi program kerja, 3) penerapan Iptek pengangkatan/pembersihan eceng gondok, 4) evaluasi hasil kerja/program, 5) tindaklanjut perbaikan. 
2) Manajemen; Prosedur kerja meliputi: 1) identifikasi masalah administrasi dan manajemen usaha pada kelompok usaha. 2) melaksanakan aktifitas bisnis melalui perencanaan yang efektif, 3) melaksanakan pembagian tugas pada kelompok usaha masyarakat, 4) melaksanakan aktifitas bisnis sesuai perencanaan dan pembagian tugas kelompok, 5) melaksanakan fungsi kontrol terhadap aktifitas bisnis kelompok untuk memastikan berjalan sebagaimana perencanaan yang telah ditetapkan sebelumnya. 6) merancang desain/motif bunga, ikan, pohon kelapa dan motif masjid sebagai produk anyaman eceng gondok dengan ciri khas unggulan desa Wisata lingkungan Iluta.

3) Sumberdaya Manusia; Prosedur kerja meliputi: 1) identifikasi kebutuhan sumberdaya manusia yang menggerakkan usaha untuk urusan administrasi, produksi dan pemasaran, 2) merekrut tenaga kerja sesuai dengan jumlah kebutuhan, kualifikasi pendidikan dan kompetensi sebagaimana diuraikan pada solusi dan luaran halaman sebelumnya, 3) memberikan pendidikan dan pelatihan bagi semua karyawan sebelum mereka ditempatkan dan bekerja memproduksi anyaman, 4) membuat kontrak kerja dengan semua karyawan yang dipekerjakan, 5) melakukan pengawasan pada semua karyawan yang bekerja untuk memastikan terlaksananya berbagai tugas yang telah ditetapkan. 6) memberikan pelatihan keahlian merancang motif baru unggulan bercirikan desa wisata lingkungan iluta, dengan motif ikan, ikan, pohon kelapa dan sebagainya.

Secara rinci program kerja pengembangan desa mandiri melalui penguatan sumber daya manusia dan Iptek manajemen pemanfaatan eceng gondok sebagai produk unggulan dapat dijelaskan sebagai berikut:

Pertama, penanganan masalah eceng gondok yang begitu cepat mengancam ekosistem danau limboto khususnya disekitar desa wisata lingkungan Iluta (dua dusun pesisir).

Masalah : Cepatnya pertumbuhan eceng gondok dapat menyebabkan pendangkalan danau limboto secara masif.

Solusi : Pengangkatan eceng gondok di pesisir danau limboto Desa Iluta dan pendaratan Presiden Soekarno, dengan tahapan dirinci pada Tabel 1.

Luaran : Pengurangan pendangkalan danau Limboto khususnya di sekitar Desa Iluta dan wisata pendaratan Presiden Soekarno.

Tabel 1. Rincian Kegiatan Penyiapan Eceng Gondok

\begin{tabular}{lllll}
\hline No & Rincian Kegiatan & Frekuensi & Penanggungjawab & Ket. \\
\hline 1 & Sosialisasi PPDM kepada & 2 Kali & Ketua kelompok \\
masyarakat & setahun & kerja masyarakat & $\begin{array}{l}\text { 2 Dusun } \\
\text { (1000) Kg }\end{array}$ \\
\hline 2 & Pengangkatan eceng gondok di & 2 Kali & Ketua kelompok & 2 Dusun \\
& pesisir danau Limboto & setahun & masyarakat & (1000) Kg \\
\hline 3 & Penyiapan eceng gondok & 2 Kali & Ketua kelompok & 2 Dusun \\
& sebagai bahan baku utama & setahun & kerja masyarakat & (1000) Kg \\
& Pemilihan/Pemilahan & & & \\
& Penjemuran/pengeringan & & & \\
& Bahan baku siap dipakai & & & \\
\hline
\end{tabular}

Sumber: Hasil Identifikasi lapangan Tahun 2019. 
Kedua, operasionalisasi kegiatan usaha kelompok membutuhkan penerapan Iptek manajemen usaha dan produksi ragam kerajinan eceng gondok. Oleh karena itu dibutuhkan Scientific manajemen untuk menjawab masalah pokok tata kelola usaha (Emiyokwemba, 2018).

Masalah : Kurangnya kapasitas manajemen usaha kelompok sasaran.

Masalah manajemen merupakan masalah kunci dalam memulai pengelolaan usaha. Kelompok UKM yang dibentuk dapat bertahan dan mampu berkembang sangat ditentukan oleh komitmen dan konsistensi pengelola terhadap manajemen yang diterapkan secara berkesinambungan.

Solusi : Melaksanakan bimbingan teknis dan praktik fungsi manajemen yang meliputi fungsi perencanaan (Planning), Organizing, Actuating dan Controlling, yang secara rinci pada Tabel 2.

Luaran : Kelompok UKM memahami fungsi manajemen dan mengaplikasikannya secara nyata dan terukur dalam praktik usaha.

Tabel 2. Penerapan Iptek Manajemen

\begin{tabular}{|c|c|c|}
\hline No & Materi Pokok & Rincian \\
\hline 1 & $\begin{array}{l}\text { Fungsi } \\
\text { Planing }\end{array}$ & $\begin{array}{l}\text { Kelompok UKM wajib mengetahui apasaja yang harus } \\
\text { direncanakan dalam bisnis, bagaimana membuat perencanaan } \\
\text { dalam satu periode, bagaimana melakukan prioritas } \\
\text { perencanaan dan bagaimana membuat perencanaan yang } \\
\text { realistis. Termasuk didalamnya bagaimana rencana } \\
\text { penggunaan sumberdaya baik sumberdaya manusia maupun } \\
\text { sumber daya keuangan, bahan, peralatan kerja dan akses pasar, } \\
\text { bagaimana mengembangkan produk kerajinan anyaman eceng } \\
\text { gondok dengan ciri khas Desa Iluta }\end{array}$ \\
\hline 2 & $\begin{array}{l}\text { Fungsi } \\
\text { Organizing }\end{array}$ & $\begin{array}{l}\text { kelompok UKM wajib mengetahui bagaimana menetapkan } \\
\text { sumberdaya apa saja yang dibutuhkan, bagaimana } \\
\text { mengelompokkan dan memaksimalkan sumberdaya. }\end{array}$ \\
\hline 3 & $\begin{array}{l}\text { Fungsi } \\
\text { Actuating }\end{array}$ & $\begin{array}{l}\text { Kelompok UKM mampu mengoperasionalisasikan setiap } \\
\text { rencana bisnis secara bertahap sampai mencapai target realistis } \\
\text { yang ditetapkan dengan penyesuaian sedapat mungkin } \\
\text { terhadap kondisi pasar yang berkembang }\end{array}$ \\
\hline 4 & $\begin{array}{l}\text { Fungsi } \\
\text { Controlling }\end{array}$ & $\begin{array}{l}\text { kelompok UKM wajib memastikan bahwa setiap tahapan } \\
\text { rencana bisnis yang diimplementasikan berjalan dengan efektif, } \\
\text { dengan cara cepat melakukan identifikasi dan tindakan nyata } \\
\text { terhadap setiap masalah atau perubahan lingkungan yang } \\
\text { terjadi setiap saat }\end{array}$ \\
\hline
\end{tabular}

Sumber: Hasil Identifikasi Lapangan Tahun 2019.

Ketiga, sumberdaya Manusia (SDM) baik secara kuantitatif maupun kualitatif.

Masalah: Belum teridentifikasinya kebutuhan sumberdaya manusia baik untuk pananganan eceng gondok maupun dalam penerapan Iptek ragam produk eceng gondok.

Solusi : Melakukan pemetaan tenaga kerja yang berfokus pada dua hal, yaitu tenaga pengelola administrasi dan pengrajin eceng gondok. Pemetaan dimaksud menentukan tenaga kerja seperti apa yang dibutuhkan dalam menjalankan 
kegiatan usaha. Selama ini tenaga admin tidak menguasai dengan baik aspek apa saja yang harus dikerjakan dan disiapkan dalam mengelola usaha kerajinan eceng gondok. Secara rinci kebutuhan SDM diurai pada Tabel 3.

Luaran : Tertatanya dan terpenuhinya kebutuhan sumberdaya manusia sebagai unsur utama dalam penggerak usaha baik dari aspek manajemen dan produksi anyaman eceng gondok unggulan desa wisata lingkungan Iluta.

Tabel 3. Kebutuhan Sumberdaya Manusia pada dua kelompok UKM

\begin{tabular}{llll}
\hline Spesifikasi & Admin & Produksi & Pemasaran \\
\hline Jumlah & 1 & 25 & 2 \\
\hline Kualifikasi & Minimum & Minimum SMP & Minimum D3 \\
Pendidikan & SMA/SMK & Sederajat & Ekonomi \\
\hline Kompetensi & Memiliki pengetahuan & Memiliki pengetahuan & Memiliki pengetahuan \\
& dasar administrasi dan & dasar tentang anyaman & manajemen pemasaran \\
& manajemen; & eceng gondok; & dan distribusi produk \\
& Mampu & Memiliki kemampuan & UMKM; \\
& mengoperasikan & desain dan kombinasi & Mampu menggunakan \\
& komputer/internet. & eceng gondok dan rotan; & komputer untuk aplikasi \\
& & Memiliki keahlian desain & office; \\
& & dan motif ragam produksi & Mampu menggunakan \\
& & eceng gondok sebagai & fasilitas media online. \\
& & unggulan khas desa & \\
& wisata Iluta. & \\
\hline
\end{tabular}

Sumber: Hasil Identikasi Lapangan Tahun 2019

Gambaran penerapan Iptek diperlukan untuk memperjelas rencana kerja lapangan. Penerapan Iptek Pengangkatan eceng gondok menggunakan mekanisme penjaring dipesisir danau desa wisata Iluta. Gambaran Ipteknya meliputi: 1) Sosialisasi terbuka melalui spanduk, papan informasi dan media online facebook dan watsup tentang gerakan pembersihan eceng gondok melalui PPDM Desa wisata lingkungan Iluta. 2) Penggunaan instrumen terukur pemetaan kelompok kerja masyarakat penanggungjawab berdasarkan wilayah cakupan target pengangkatan eceng gondok di pesisir danau limboto desa wisata lingkungan Iluta. 3) Penggunaan peta tematik lingkungan target operasi pembersihan eceng gondok di pesisir danau limboto desa wisata lingkungan Iluta, secara bertahap terukur, terkoordinasi dan terintegrasi. 4) Penggunaan Iptek pemilahan dan pemilihan eceng gondok sebagai bahan baku ragam produk anyaman khas desa wisata lingkungan Iluta berdasarkan standar quality instrumen. 5) Penggunaan Iptek pengeringan bahan baku eceng gondok melalui mesin pengering untuk menghasilkan kadar air standar pemanfaatan bahan sebagai produk anyaman.

Gambaran penerapan Iptek manajemen pada kelompok sasaran dilaksanakan melalui metode teori dan praktik fungsi dan unsur manajemen. Manajemen yang baik dalam suatu industri sangat menentukan keberhasilan dan keberlanjutan usaha (Octaviani, 2018). Salah satu aspek penting dalam manajemen adalah continous business plan method. Penerapan Iptek Continous Business Plan Method antaranya terdiri dari: Planing dimaksud ialah bisnis produk anyaman eceng gondok yang terencana dan tersistematis. Organizing dimaksud adalah kelompok yang terstruktur sesuai kebutuhan bisnis. Actuating dimaksud adalah terkoordinasi dengan stakeholder baik pemerinah desa, Bumdes, pemerintah kecamatan/kabuapaten dan perguruan tinggi. Controlling dimaksud ialah penggunaan instrumen pedoman kerja yang diatur dan disepakati bersama untuk pencapaian target secara bertahap. Gambaran penerapan Iptek sumber 
daya manusia melalui bimtek. Salah satu materi pokok yang penting adalah bimtek SDM penerapan Iptek standar bahan baku eceng gondok sesuai standar mutu/kualitas produk. Bimtek SDM Penerapan Iptek mesin ouven/pengering bahan baku eceng gondok. Penerapan Iptek motif/desain pada ragam produk eceng gondok. Bimtek SDM Penerapan aplikasi komputer desain grafis untuk motif unggulan produk khas desa wisata lingkungan Iluta.

Dalam upaya mencapai target program dan luaran yang telah dijelaskan sebelumnya maka dibutuhkan evaluasi. Untuk mendapatkan hasil yang maksimal, maka evaluasi dilakukan pada setiap bulan dan akhir tahun selama tiga tahun, yaitu tahun 2019, 2020 dan 2021. Adapun evaluasi tahunan dimaksud dapat dirinci sebagai berikut: 1) jangkauan pembersihan/pengangkatan eceng gondok di pesisir danau limboto desa wisata lingkungan Iluta, pembersihan dilaksanakan setiap enam bulan. Luas danau yang dibersihkan ditingkatkan pada tahun kedua dan ketiga, 2) semua rencana program bidang manajemen terlaksana dengan baik, apakah target program pada aspek manajemen terpenuhi dan apakah luaran aspek manajemen pada kelompok usaha masyarakat berhasil. Apabila terdapat kendala dalam implementasi perbaikan aspek manajemen sedapat mungkin dicarikan solusi untuk perbaikan sehingga dapat dilanjutkan perbaikan untuk program tahun selanjutnya. 3) apakah sumberdaya manusia yang telah direkrut dan dipekerjakan mampu mencapai target yang telah ditetapkan, yaitu mampu melakukan penataan administrasi dan manajemen secara profesional, mampu melakukan proses produksi sesuai dengan target dan kualitas yang dimaksud, mampu mencapai target penjualan produk di pasar lokal se-Provinsi Gorontalo.

\section{SIMPULAN}

Hasil implementasi kegiatan Program Pengembangan Produk Unggulan Daerah dapat disampaikan beberapa simpulan sebagai berikut: 1) pemanfaatan eceng gondok sebagai produk kerajinan tangan dapat membantu mengurangi pendangkalan danau Limboto, khususnya yang berada di kawasan pesisir pedesaan, 2) mulai tumbuhnya kemampuan manajemen praktis dalam pengelolaan usaha pada kelompok masyarakat sebagai sasaran program, 3) meningkatnya kemampuan sumber daya manusia masyarakat pesisir danau Limboto dalam hal tata kelola dan pemanfaatan eceng gondok sebagai ragam produk kerajinan tangan yang memiliki nilai ekonomi.

\section{Ucapan Terima kasih}

Implementasi Program Pengembangan Desa Mitra bagi kelompok masyarakat Desa Iluta Kecamatan Batudaa Kabupaten Gorontalo telah dilaksanakan sesuai rencana kerja dan capaian target. Dalam penerapan Iptek tim pelaksana telah dibantu berbagai pihak. Oleh karena itu ucapan terimakasih disampaikan kepada: 1) Direktorat riset dan pengabdian masyarakat, Kemristekdikti, 2) Pemerintah daerah Kabupaten Gorontalo dan pemerintah Desa Iluta, 3) LPPM Universitas Negeri Gorontalo, 4) Kelompok masyarakat sasaran, tim pelaksana dan mahasiswa, 5) Semua pihak yang telah membantu suksesnya kegiatan Program Pengembangan Desa Mitra.

\section{REFERENSI}

Aries, E. F. (2010). Design action research. Malang: Aditya Media Publishing 
Damanik, J., \& Weber, H. F. (2006). Perencanaan ekowisata: Dari teori ke aplikasi. Yogyakarta: Puspar UGM dan Andi.

Dungga, W. A., Sulila, I., \& Aneta, Y. (2018). Pentingnya aspek hukum pelestarian danau Limboto dan pemanfaatan eceng gondok sebagai produk kerajinan tangan khas masyarakat Desa Buhu Kabupaten Gorontalo. Jurnal Pengabdian Kepada Masyarakat, 24(2), 617-622.

Fahmi, I. (2015). Manajemen Strategis. Teori dan Aplikasi. Bandung: Alfabeta.

Fandeli, C. (2000). Pengertian dan konsep dasar ekowisata. Yogyakarta: Fakultas Kehutanan UGM.

Kartasapoetra, G. (2000). Makro ekonomi; Edisi Kedua. Jakarta: Raja Grafindo Persada.

Kuncoro, M. (2006). Usaha Kecil di Indonesia: Profil. Masalah dan strategi pemberdayaan. Jurnal Usaha Kecil Indonesia. 1-19

Mubarak, Z. (2010). Evaluasi pemberdayaan masyarakat dari proses pengembangan kapasitas program PNPM Mandiri Perkotaan di Desa Sastrodirjan Kabupaten Lamongan (Unpublished master's thesis). Universitas Diponegoro, Semarang, Indonesia.

Octaviani, V., Narti, S., \& Nurwita, S. (2018). Peningkatan sumber daya masyarakat desa dalam binaan pusat kegiatan belajar masyarakat (PKBM). Jurnal Pengabdian Pada Masyarakat, 3(2), 117-124.

Satria, D. (2009). Strategi pengembangan ekowisata berbasis ekonomi lokal dalam rangka program pengentasan kemiskinan di wilayah Kabupaten Malang. Journal of Indonesian Applied Economics, 3(1), 37-47.

Sulila, I. (2016). Pemberdayaan masyarakat melalui peningkatan kapasitas manajemen dan mutu produk pada kelompok kerajinan Karawo di Desa Bongo Kabupaten Gorontalo. Jurnal Pengabdian Kepada Masyarakat, 22(3), 96-102.

Sulila, I. (2018). Penguatan kapasitas tata kelola keuangan dan produksi bagi kelompok masyarakat pengrajin karawo Desa Wisata Religius Bongo Kabupaten Gorontalo. Jurnal Pengabdian Kepada Masyarakat, 24(2), 610-616. 